\title{
Technological Interventions for Food Security
}

\author{
Pratapbhanu Singh Bhadoria
}

\begin{abstract}
To have sustainable production, water saving rice production technology i.e. System of Rice Intensification (SRI), that saved $70-80 \%$ seed and $25-30 \%$ irrigation water requirement was introduced. Also Organic Farming technology was practiced in both SRI and conventional system for quality improvement in soil health and the food grain. Multiple options have been explored for nutrient management in both the types of transplanting. Organic fertilizer, chemical fertilizer, mix of Organic and chemical fertilizers, etc have been tried. A significant increase in $\mathrm{pH}$ has been observed especially in the fields, which were primarily treated with Organic fertilizers Also Organic carbon was found to be $0.29 \%$ (average) in the chemically treated plots while $0.47 \%$ (average) in organically treated ones. Average $\mathrm{N}$ is $220 \mathrm{~kg} / \mathrm{ha}, \mathrm{P}$ is $25 \mathrm{~kg} / \mathrm{ha}$ and $\mathrm{K} 2 \mathrm{O}$ is 200 $\mathrm{kg} / \mathrm{ha}$. Which is almost two times higher than the initial NPK values.

To promote crop diversification, cash crop like sweet corn, peanut and soybean were introduced in addition to rice. Framers could harvest the dry season rice with yield ranging from 5 to $5.5 \mathrm{t} / \mathrm{ha}$ after bearing the loss due to incidental rain during maturity stage of the crop Also the farmers could realize higher return from other crops such as sweet corn, peanut, and sesame with less fertilizer, labor and water. Furthermore, vermicomposting technology was demonstrated among the farmers to encourage them to take up organic farming.

Farmers had preference to grow rice only. The most important impact of this study had been is the change in the mind set of farmers that they can now grow other soil restoring crops, with less labour, water and fertilizer. Farmers had been planting only IR36 during Kharif, but introduction new varieties like Hybrid Bio (799), had yielded 7-9 ton /ha.
\end{abstract}

Keywords - Technological, Food, Security.

\section{INTRODUCTION}

Global food demand is expected to be doubled by 2050 , while environment, water resources are continuously shrinking and soil quality deteriorating continuously. The demand for food grain is expected to grow more than $100 \%$ from 2000 to 2030 in India. The food demand in the year 2000 was 192 million tonnes (MT) and by 2030 it will be around 335 MT. In 2014, the population of undernourished people was around 190 million. Climate change, diversion of arable lands to urbanization, industrialization and bio-fuel production has aggravated the food crisis. Further, NFSA (National Food Securities Act, 2013) is aimed to provide subsidized food to two-third of the 1.2 billion population of the country.

Professor, Agricultural and Food Engineering Department, Indian Institute of Technology Kharagpur, Email: pbsb@agfe.iitkgp.ernet.in
To meet with the demand and address the various issues, there is a need to increase food grain productivity with development of sustainable low cost technology and minimize the loss of grains during processing and storage by creating required infrastructure and appropriate technologies.

Annual food grain production has been gradually increasing every year with the estimated produce of 264 MT for 2013-14. India needs to double its agricultural productivity by 2040 to reduce supply and demand gap. Increasing the food grain production has become a challenge because of diminishing per capita arable land and availability of irrigation water resources and expanding abiotic and biotic stresses under climate change/variability. At the same time, huge yield gap $(>50 \%)$ between attainable and actual farmers yield in many parts of the country including eastern India offers the scope for meeting the challenge. Further, high agricultural output also requires better storage and logistics support as the loss due to improper storage and handling of food grain is as high as $25-35 \%$. Increasing food grain productivity and minimizing post-harvest losses can be possible through implementation of scientific production and processing technologies in farmers' field.

\section{METHODOLOGY AND RESULTS}

IIT Kharagpur has adopted 14 acres of land from 14 farmers in Kenthia village (Kharagpur Block-II, Paschim Medinipur), located within $10 \mathrm{~km}$ from the Institute campus. The land was barren for last 5-7 years without any crop cultivation even in rainy season. As rice is the major crop in the region, farmers had no interest to grow crops other than rice cultivation during dry season cause depletion of ground water level as this is a high water demanding crop. Therefore, to have sustainable production, we introduced water saving rice production technology i.e. System of Rice Intensification (SRI) that generally saves $70-80 \%$ seed and $30-40 \%$ irrigation water requirement. In addition, Organic Farming technology was practiced in both SRI and conventional system for quality improvement in soil health and the food grain. To promote crop diversification, cash crop like sweet corn, peanut and soybean were introduced in addition to rice. This will increase the farmers' income as well as improve soil health and minimize the irrigation water requirement. Furthermore, vermicomposting technology was demonstrated among the farmers to encourage them to take up organic farming. Treatment of farmer's pond by applying bentonite clay was implemented as a component of Integrated Farming System to store more water throughout the year. Farmers can grow fish in pond and use the water for irrigation purpose 
that will improve their economy. Framers could harvest the dry season rice with yield ranging from 5 to $5.5 \mathrm{t} / \mathrm{ha}$ after bearing the loss due to incidental rain during maturity stage of the crop. This finds are confirmed with Swain and Bhadoria et.al. The harvested rice yield was about two times higher than the yield of farmers' practice and the farmers had realized higher return from other crops such as sweet corn, peanut, and sesame.

A Field Day were organized to develop awareness among the farmers of this village and neighboring villages on scientific food grain production. Professors from IIT, Agricultural officers of West Bengal Govt., and Panchayat level official participated in the Field Day. Agricultural officers and farmers from neighboring village want to have similar project in many locations that will help capacity building of farmers on scientific production technologies and hence production improvement.

In the following wet season (June-October) of 2015, seven high yielding rice cultivars including hybrid cultivars were introduced for comparative assessment of varietal effect. The effect of planting system such as drum seeding, transplanting and SRI were tried for the demonstration. Similarly, different nutrients management technologies like chemical fertilizer, organic fertilizer, integrated management, reduced fertilizer, and SPAD-N management were demonstrated to maintain higher yield with minimum input application. This finds are confirmed with Bhadoria and Swain et.al. Farm machinery like power tiller, transplanter, weeder, and harvester are used by the farmers for timely operations and to minimize the labour cost. A small model has been developed around this project, which can be used to develop other villages in a similar way.

\section{A. Land Preparation}

Small adjacent fields belonging to a single farmer were merged to make larger fields. Primary and secondary tillage was done by tractor driven plough followed by leveling. Converting 120 small plots into 46 larger plots.

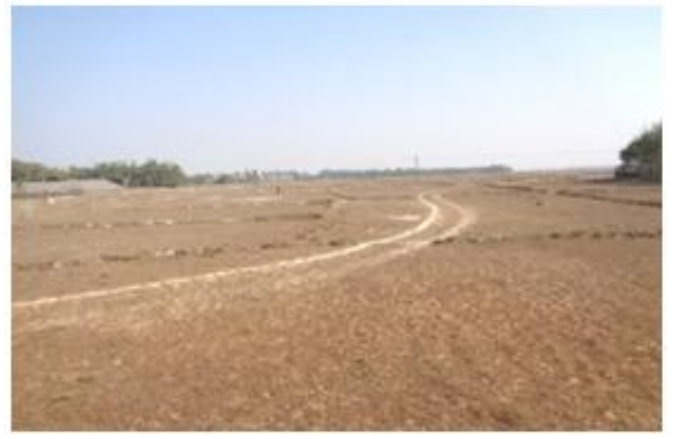

Barren land from past 5-7 years

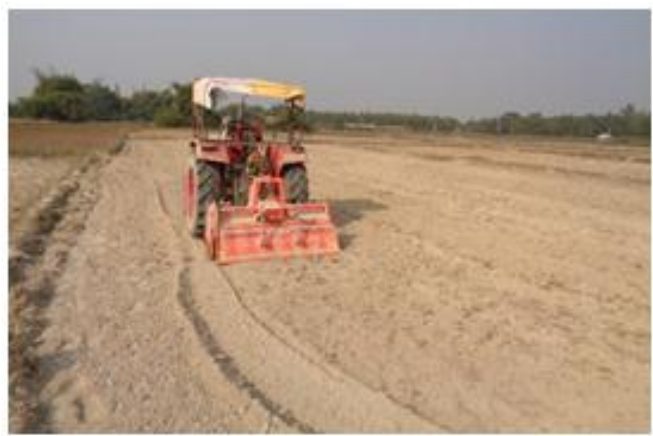

Ploughing and leveling of soil

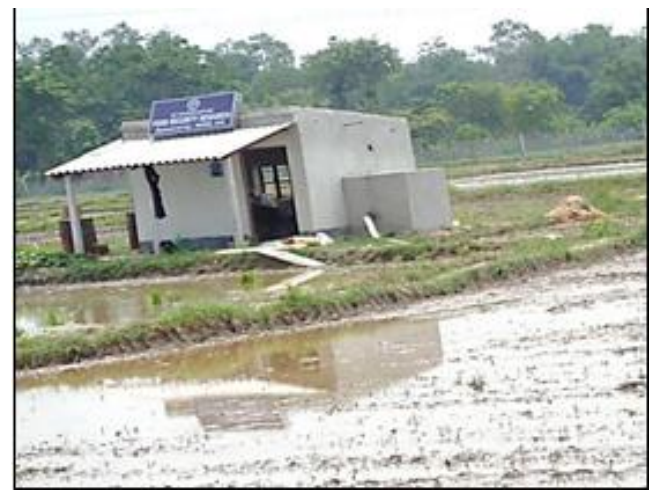

6hp pump installed Puddling of field

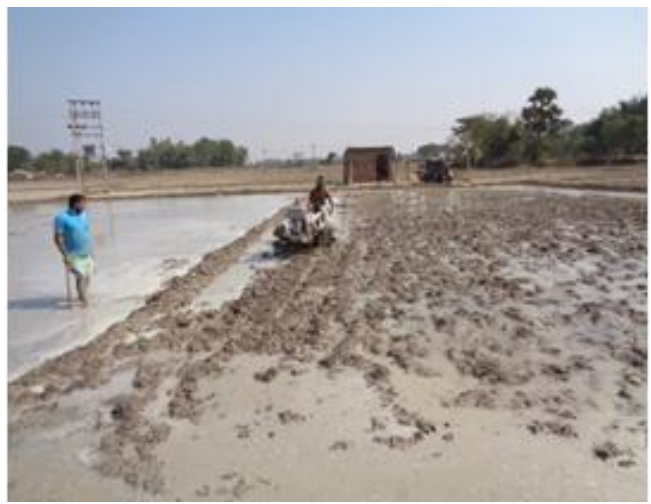

Puddling of field

\section{B. Water Saving Rice Production Technology}

The production technology of System of Rice Intensification (SRI), which saves 70-80-seed and 30-40\% water requirement demonstrated in the farmer's field.

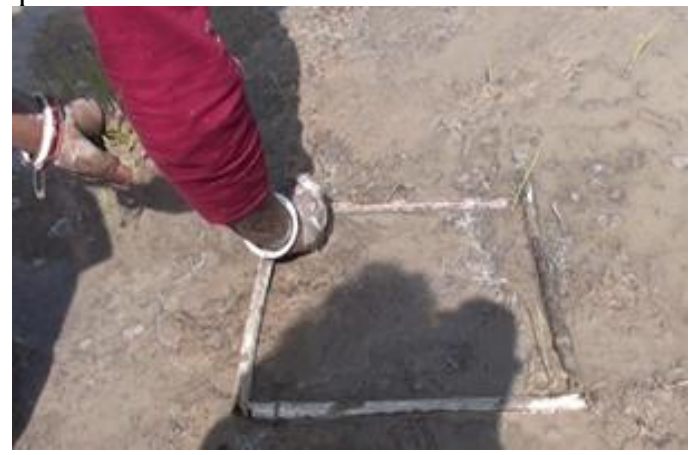

SRI method 


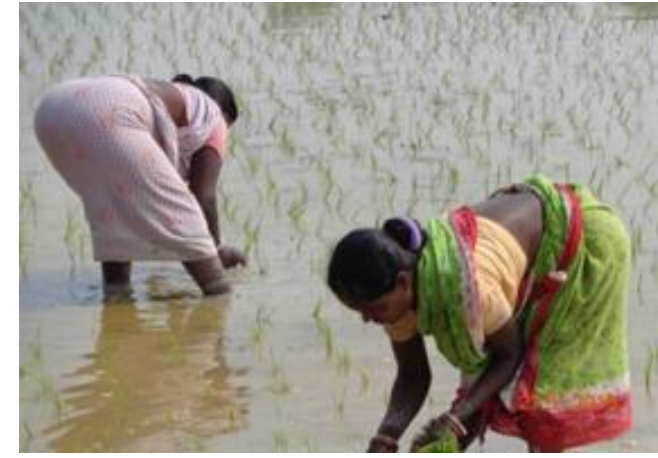

Conventional (TRP) method

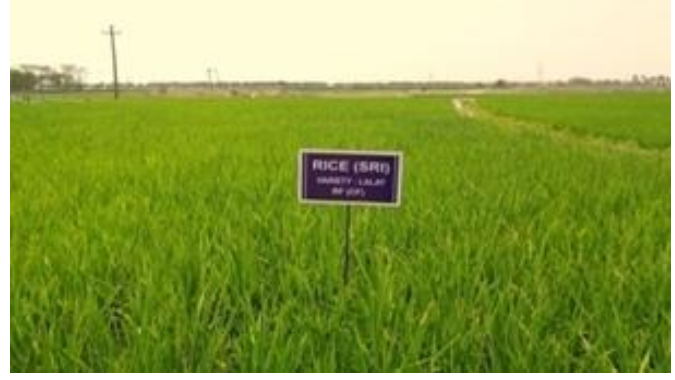

SRI method rice field

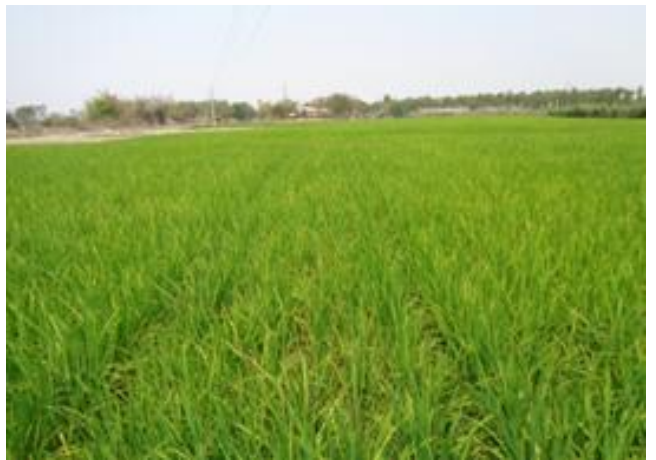

Conventional method (TRP) rice field

\section{Crop Diversification}

Farmers had preference to grow rice crop only. However, considering the land topography, water demand and soil fertility, we introduced high value and soil restoring crops such as sweet corn, sesame, soybean and peanut. Sweet corn is an important vegetable cash crop consumed widely for its taste and nutritional benefits. It is rich in vitamins and minerals. Leguminous crops like soybean and peanut will add biological $\mathrm{N}$ and improve soil health for sustainable production, besides being rice source of protein and oil.

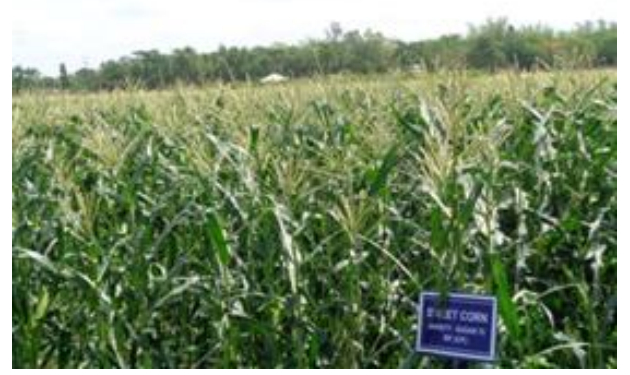

Sweet corn field

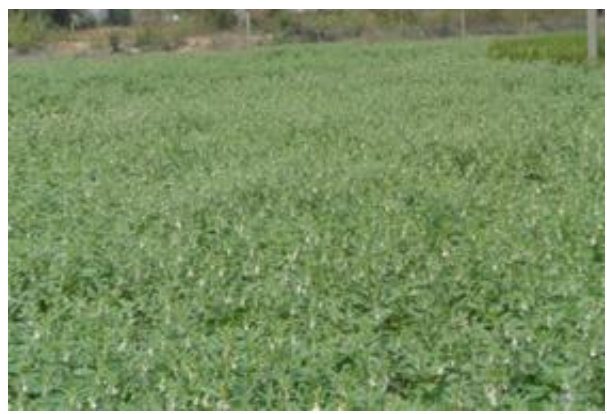

Sesame field

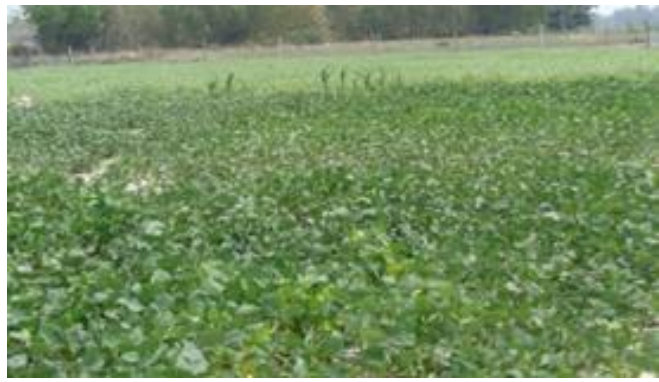

Soybean field

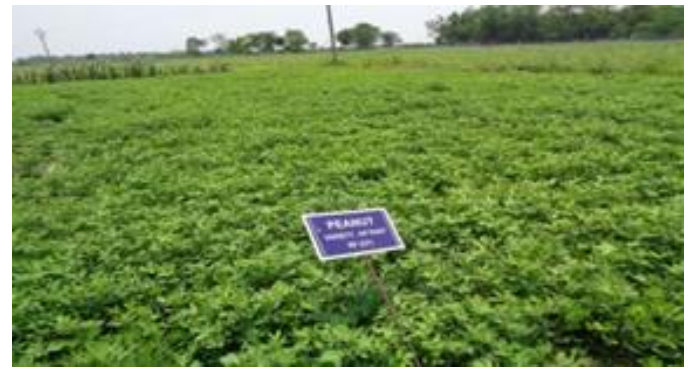

Peanut field

\section{Planting and Harvest Mechanization}

Drum seeder, transplanter and ripper were been introduced to farmers for mechanization of agricultural system. This mechanized equipment is use for planting of paddy seedling and harvesting of the paddy at mature stage respectively, which eliminates the use of massive manpower utilization in single process. Earlier the farmers habited with manual paddy transplanting and harvesting process.

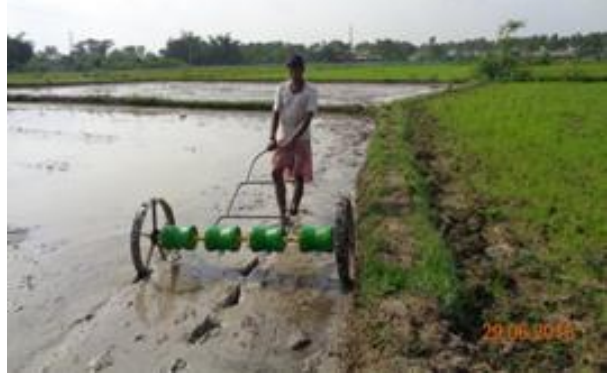

Drum seeder 


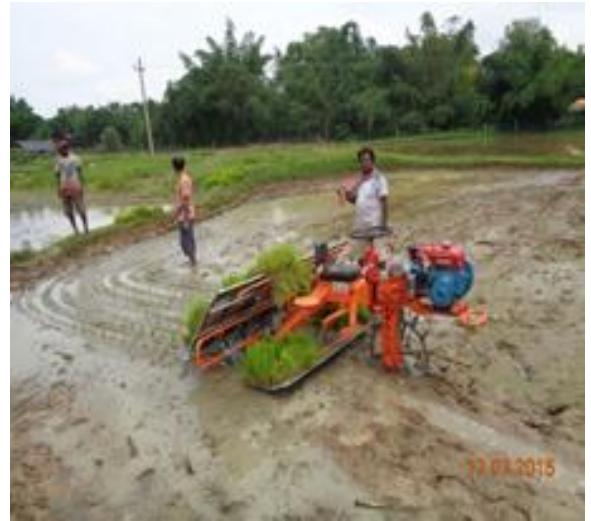

Transplanter

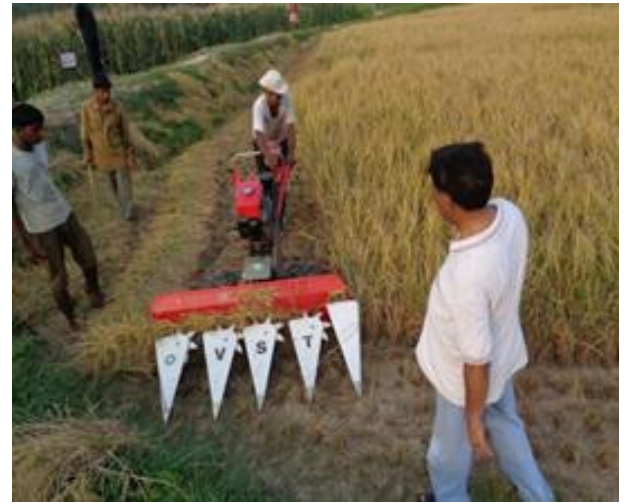

Mechanized paddy harvesting

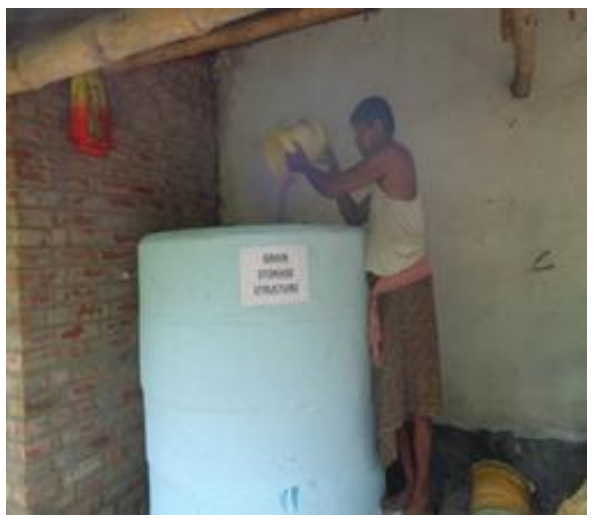

Paddy grain storage structure

E. Introducing New Paddy Varieties During Kharif Season

During Kharif season new paddy varieties were introduced at farmers field.

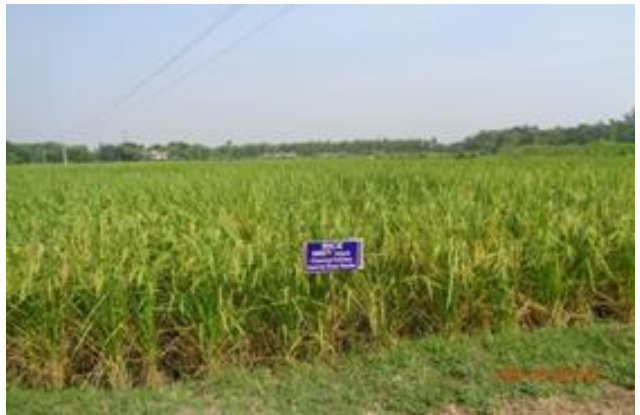

Hybrid, transplanted by drum seeder

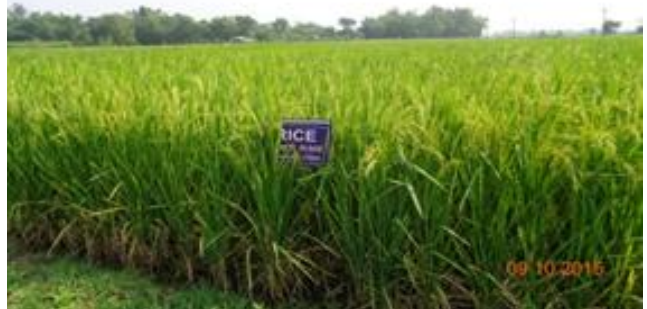

Hybrid, transplanted by transplanter

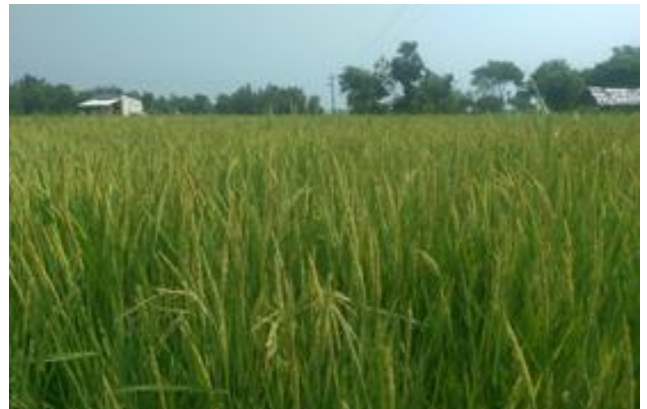

Pravati (Dehradun Basmati)

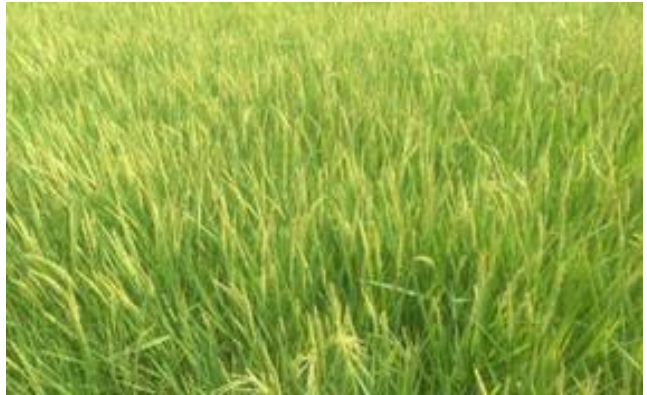

Badshabhog at flowing stage

\section{F. Vermicomposting}

Cow dung, water hyacinth and farm wastes are used as inputs for the composting process with 2.5-3.0 kg earthworms (Eisenia foetida) in each bed of size $1.8 \mathrm{~m} \times 1.2 \mathrm{~m} \times 1 \mathrm{~m}$. Each bed is expected to produce $100 \mathrm{~kg}$ of vermicompost in one cycle of 60 days.

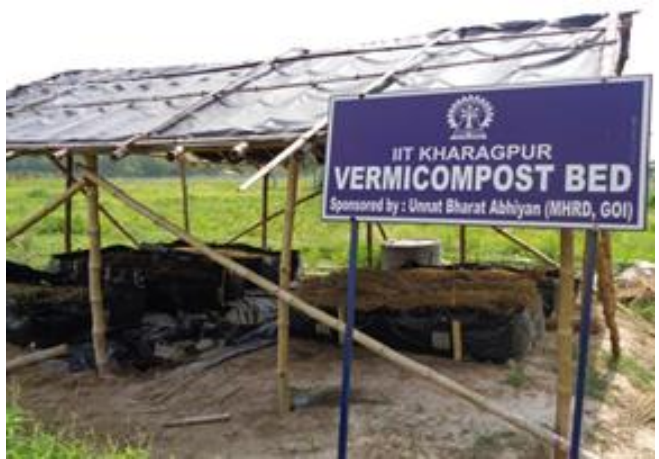

Vermicomposting shade 


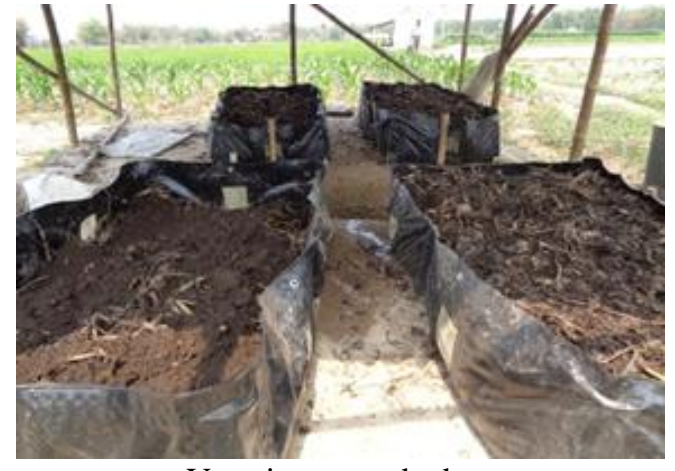

Vermicompost beds

\section{G. Water Harvesting Cum Aquaculture}

To increase economy of the poor farmers, pond size $25 \mathrm{~m} \mathrm{x}$ $15 \mathrm{~m} .5 \mathrm{~m} \times 2 \mathrm{~m}$ is renovated to store rainwater and grow fish as component of integrated farming system. Pond was plastered with bentonite clay to check the water loss through seepage. The stored rainwater will be used to provide lifesaving irrigation.

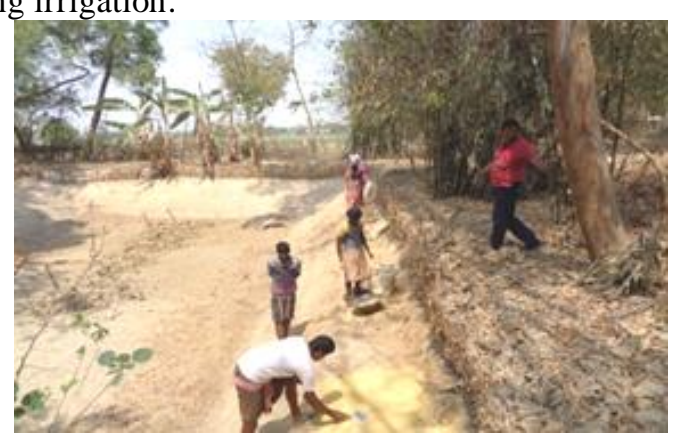

Treatment of pond with bentonite clay

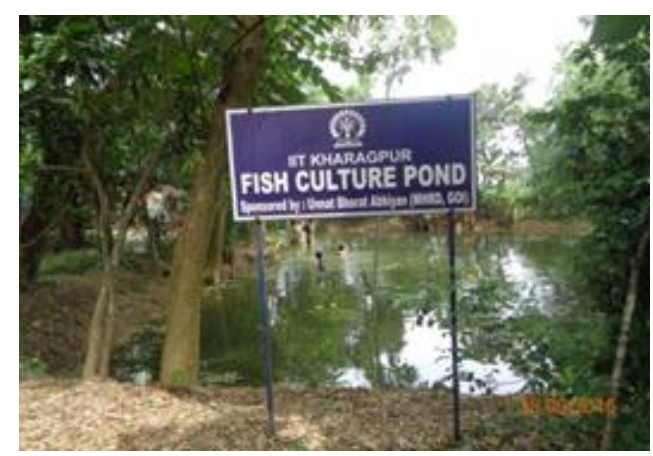

Treated pond with fish

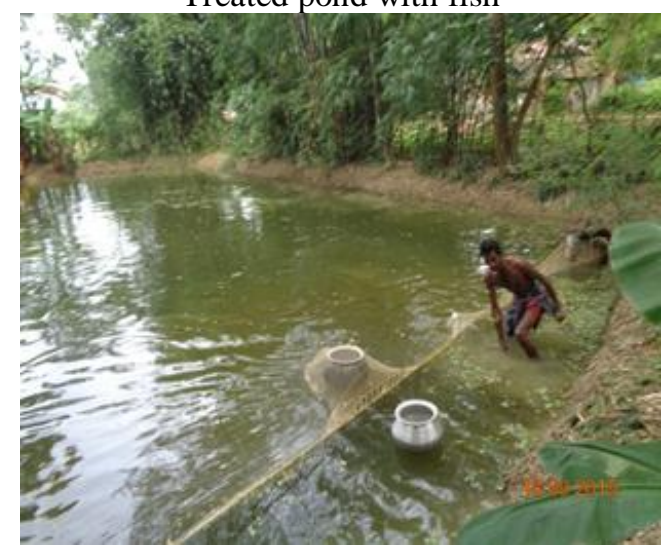

Seine fishing in pond

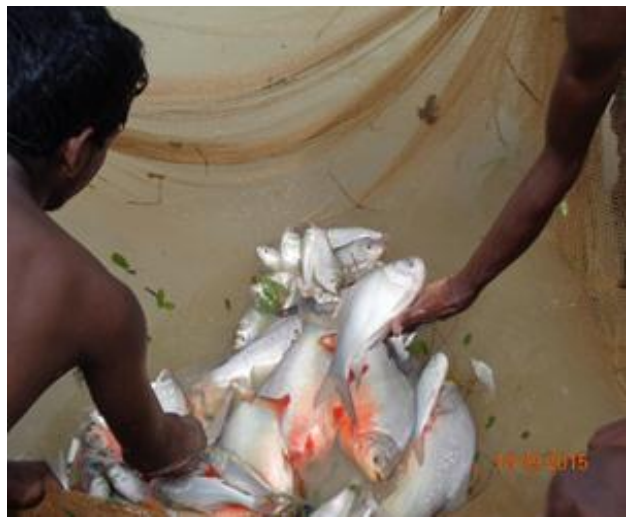

Fish in net

\section{REFERENCES}

[1] Satapathy, S.S., Swain, D.K., Pasupalak, S., and Bhadoria, P.B.S. (2015). Effect of elevated [CO2] and nutrient management on wet and dry season rice production of subtropical India. The Crop Journal. Elsevier, (DOI: 10.1016/j.cj.2015.08.002).

[2] Satapathy, S.S., Swain, D.K., Shrivastava, S.L., Bhadoria, P.B.S. (2014). Effect of elevated carbon dioxide and nitrogen management on rice milling qualities. Euro. Food Resch. Technology. Springer. 238, 699-704. $(\mathrm{IF}=1.436)$ http://dx.doi.org/10.1007/s00217-013-2146-z

[3] Bhadoria, P.B.S., Dessougi, H. El., Liebershach, H. and Claassen, N. (2004). Phosphorus uptake kinetics, size of root system and growth of maize and groundnut in solution culture. Plant Soil. 262, 327-336. http://dx.doi.org/10.1023/B:PLSO.0000037051.16411.03

[4] Prakash, Y.S., Bhadoria, P.B.S., Rakshit, A, and Wais, A. (2003). Response of Basmati rice to integrated nutrient sources in lateritic soil of eastern India. Italian J. Agron. 6, 143-150. 